\title{
Factors that Increase the Need for Surgery in Chiari Malformation Type 1 Patients Morphometric Analyses in Chiari Patients
}

\author{
Tip 1 Chiari Malformasyonlu Hastalarda Ameliyat Gereksinimini Artıran Faktörler \\ Chiari Hastalarında Morfometrik Analiz \\ ๑ Enes Akkaya, ๑ Ahmet Kayhan* \\ 'University of Health Sciences Turkey, Şişli Hamidiye Etfal Training and Research Hospital, Clinic of Neurosurgery, Istanbul, Turkey \\ * University of Health Science Turkey, Haseki Training and Research Hospital, Clinic of Neurosurgery, Istanbul, Turkey
}

\section{Abstract}

Aim: The causes of the syringomyelia in Chiari are not certainly defined. We have done morphometric analyses which can be useful to understand natural course and causes which increase the surgery requirement of patients.

Methods: Eighty nine patients (operated) and 41 patients (nonoperated) were included the study. Investigations were done as randomized. Accompanying syringomyelia, area of foramen magnum, herniated tonsil volume and clivo-dental angle were compared between operated and control groups.

Results: Syringomyelia was seen in $50 \%$. The mean values of FMA were $765.2 \pm 119.5 \mathrm{~mm}^{2}$. The mean value of critical discourse analysis (CDA) was $139.5 \pm 10.6^{\circ}$. Mean of the hydrophobicity (HTV) were found to be $54.5 \pm 24.1 \mathrm{~mm}^{3}$. The mean of age was $27 \pm 11.1$, FMA was $876.5 \pm 131.9 \mathrm{~mm}^{2}$, CDA was $141.1 \pm 10.2^{\circ}$ and HTV was $57.6 \pm 20.7 \mathrm{~mm} 3$ in the patients with syringomyelia. The mean of age was 33.9 \pm 12 , FMA was $704.3 \pm 99.6 \mathrm{~mm}^{2}$, CDA was $137,8 \pm 10,8^{\circ}$ and HTV was $51,4 \pm 26,8 \mathrm{~mm}^{3}$ in the patients who had not syringomyelia.

Conclusion: Younger age, larger FMA and CDA increase the HTV and the rate of accompanying syringomyelia. As a result, the need for surgery increases. We think that it may be beneficial to consider these parameters in patients who are evaluated for surgery.

Keywords: Arnold-Chiari malformation type 1, syringomyelia, morphometric analysis
Öz

Amaç: Hastalığın doğal seyri halen tam anlaşılamamıştır. Siringomiyelinin oluşum sebepleri de belirsizliğini kısmen korumaktadır. Biz bu çalışmada, hastalığın doğal seyrine, operasyon gereksinimine neden olan sebeplere açıklık getirmede fayda sağlayacağını düşündüğümüz morfometrik analizler yaptık.

Yöntemler: Seksen dokuz opere ve 41 opere olmayan incelendi. Incelemelerimiz randomize, retrospektif ve radyolojik olarak özel formüller vasıtasıyla yapıldı. Opere olanlarla olmayanlar arasında siringomyeli eşlik etme oranına, foramen magnum alanı (FMA), herniye tonsil hacmi (HTH) ve klivo-dental (KD) açı farklarına bakıldı. Siringomyeliye sebep olan parametrelerin oranı ayrı ayrı incelendi. HTH hesaplamasında sferoid hacim formülü ile hesaplandı. İstatistik analizi için veriler toplandı. Analizler sonrası anlamlılık değeri $p<0,05$ olarak gösterildi.

Bulgular: Siringomyeli eşlik etme oranı \%50 idi. FMA ortalaması $765,2 \pm 119,5 \mathrm{~mm}^{2}, \mathrm{KD}$ açı 139,5 $\pm 10,6, \mathrm{THH}$ ortalaması $54,5 \pm 24,1$ olarak ölçüldü. Siringomiyeli mevcut olan hastalarda ortalama yaş $27 \pm 11,1$ iken FMA ortalaması $876,5 \pm 131,9$, KDA ortalaması $141,1 \pm 10,2$ ve THH ortalaması $57,6 \pm 20,7$ olarak bulunmuştur. Siringomiyeli olmayanlarda ise ortalama yaş $33,9 \pm 12$, FMA $704,3 \pm 99,6$, KD açı $137,8 \pm 10,8$, ve $\mathrm{THH}$ $51,4 \pm 26,8$ olarak bulunmuştur.

Sonuç: Daha genç yaş, büyük foramen magnum ve klivus-dens açısı, tonsil herniasyon hacmi miktarını ve siringomiyeli eşlik etme oranını artırmakta ve bunlara sekonder operasyona gidişi daha sık hale getirmektedir. Operasyon gereksinimi açısından değerlendirilen hastalarda bu parametrelerin de gözönüne alınmasının, yararlı olabileceğini düşünmekteyiz.

Anahtar Sözcükler: Arnold-Chiari malformasyonu tip 1, siringomiyeli, morfometrik analiz
Address for Correspondence/Yazışma Adresi: Enes Akkaya, Şişli Hamidiye Etfal Training and Research Hospital, Clinic of Neurosurgery, Istanbul, Turkey

Phone: +90 5052884622 E-mail: drenesnrs@gmail.com ORCID: orcid.org/0000-0003-2503-754X Received/Geliş Tarihi: 09.12.2020 Accepted/Kabul Tarihi: 01.01.2021
${ }^{0}$ Copyright 2021 by The Medical Bulletin of istanbul Haseki Training and Research Hospital The Medical Bulletin of Haseki published by Galenos Yayınevi. ${ }^{\circledR}$ Telif Hakkı 2021 istanbul Haseki Eğitim ve Araștırma Hastanesi Haseki Tıp Bülteni, Galenos Yayınevi tarafından yayınlanmıştır. 


\section{Introduction}

Chiari malformations (CM) is a group of diseases which includes anatomical abnormalities of craniovertebral junction, cerebellum and brainstem (1). The most common form of this disease group is Chiari malformation type 1 (CM1). It was first described as "migration of conic-shaped cerebellar tonsils and caudal portions of cerebellum to the spinal canal with medulla oblongata" by Hans Chiari. CM1 is one of the most controversial issue in neurosurgery practice because of its definition, prognosis, treatment indications, selection of surgical procedure, accompanying abnormalities and diseases (2). Although one of the defined mechanisms is depletion of normal sized hindbrain to the inferior because of crowded posterior fossa caused by inadequate development of posterior cranial fossa which is derived from paraxial mesoderm; neutral progression of disease is still unclear. Although there are studies investigating the natural course of CM-1 which is less common in adults, sufficient data could not be obtained $(3,4)$. Although the symptomatic patients mostly require surgery, there is no sufficient data for asymptomatic CM-1 cases $(5,6)$. The causes of the syringomyelia are not certainly defined (7). In this study, we have done morphometric analyses which can be useful to understand natural course of CM-1 and causes which increase the surgery requirement of patients.

\section{Methods}

This retrospective study was carried out with the collaboration of Şişli Hamidiye Etfal Training and Research Hospital and Haseki Training and Research Hospital's Neurosurgery clinics. 89 patients (operation group) had surgery because of CM-1 and 41 patients (control group) followed due to the CM-1 malformation between the years 2001 and 2018 were included the study. Investigations were done as randomized and by using special radiological formulas. Accompanying syringomyelia, area of foramen magnum (FMA), herniated tonsil volume (HTV) and clivodental angle (CDA) were compared between operated and control groups. Parameters which cause syringomyelia were investigated separately. HTV were calculated with $4 / 3 \times \varpi \times\left(X_{12} \times Y_{12} \times Z_{/ 2}\right)$ spheroidal volume formula by using the largest cross-sections in three planes. The longest cross sections of herniated tonsils were measured in axial, coronal, sagittal planes and noted as $X, Y, Z$ respectively. The angle between posterior line of clivus and dens in sagittal plane was used to determine CDA (Figure 1, 2). Length of the largest anterior-posterior (A-P) and lateral sections of foramen magnum were multiplied in axial plane to calculate FMA (Figure 1, 3, 4). All data was collected for statistical analysis and range, mean and standard deviation values were calculated for each measurement parameters. Independent sample student's t test was used for normally distributed age, volume and measurements. The Spearman correlation test was used to evaluate the correlation between two continuous variables. Statistically significance value was found as $p<0.05$ (Figure 1, 5, 6).

\section{Findings}

The mean age of all patients was $30.4 \pm 12$.0. While the mean age of patients who had surgery was $27.7 \pm 10.4$, mean value of the age was found to be $36.3 \pm 10.3$ in the control group. Accompanying syringomyelia was seen in $50 \%$ of all patients, but operated patients had higher syringomyelia incidence than control group $(60.6 \%$ vs. $28.5 \%)$. The mean values of FMA in all, operated and control patients were $765.2 \pm 119.5 \mathrm{~mm}^{2}, 838.2 \pm 119.8$ $\mathrm{mm}^{2}$ and $721.9 \pm 108.2 \mathrm{~mm}^{2}$ respectively. While the mean value of CDA was $139.5 \pm 10.6^{\circ}$ in all patients, the mean CDA was $143.4 \pm 10.3^{\circ}$ in operated group and $131.1 \pm 5.2^{\circ}$ in control group. Mean of the HTVs were found to be

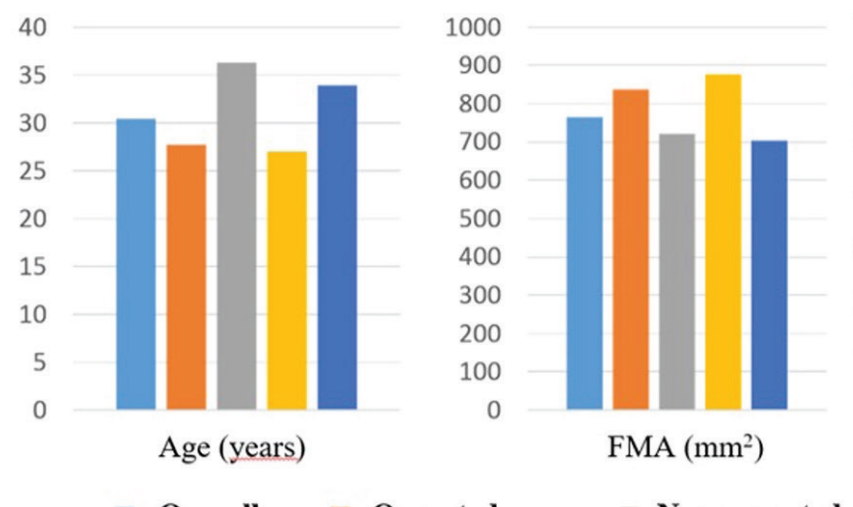

Graphic 1. Age and morphometric values of all patients. Fma: foramen magnum area, htv: herniated tonsil volume, cda: clivo-dental angle

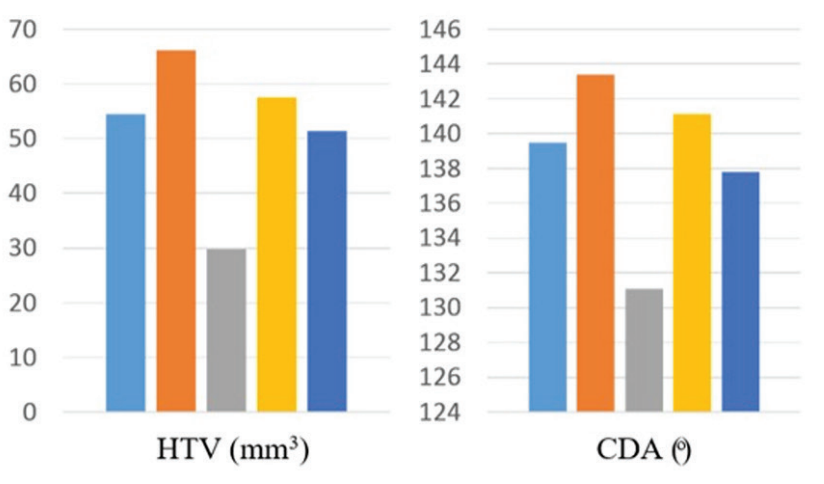

- Syringomyelia present $\quad$ Syringomyelia abscent 
$54.5 \pm 24.1 \mathrm{~mm}^{3}, 66.2 \pm 19.9 \mathrm{~mm}^{3}$ and $29.8 \pm 8.4 \mathrm{~mm}^{3}$ in the all, operated and control groups respectively (Table 1). The mean of age was $27 \pm 11.1$, FMA was $876.5 \pm 131.9$ $\mathrm{mm}^{2}, \mathrm{CDA}$ was $141.1 \pm 10.2^{\circ}$ and HTV was $57.6 \pm 20.7$ $\mathrm{mm}^{3}$ in the patients with syringomyelia. The mean of age was $33.9 \pm 12$, FMA was $704.3 \pm 99.6 \mathrm{~mm}^{2}$, CDA was $137,8 \pm 10,8^{\circ}$ and HTV was $51,4 \pm 26,8 \mathrm{~mm}^{3}$ in the patients who had not syringomyelia (Table 2, Graphic 1).

\section{Discussion}

When we analyze our results, we found higher mean values for FMA $(p<0.001)$, CDA $(p<0.001)$, HTV $(p<0.001)$ in the operated group. Increasing of FMA causes the facilitation of downward herniation of tonsils.

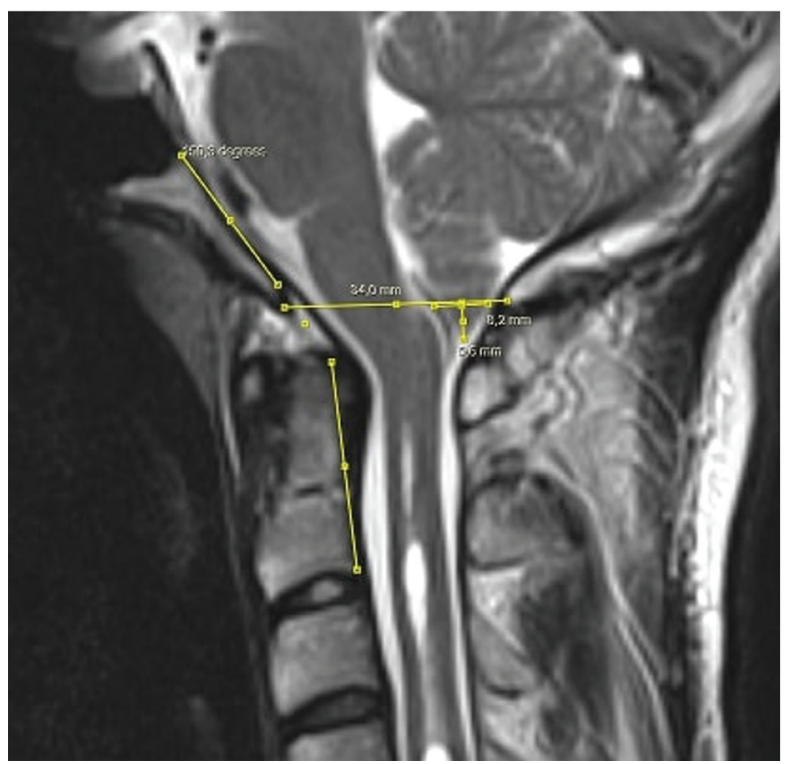

Figure 1. Measurements of clivo-dental angle, foramen magnum area and herniated tonsil volume at saggital plane

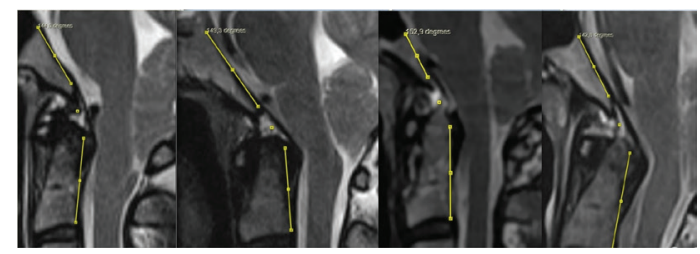

Figure 2. Examples of measurements of clivo-dental angle
The underlying mechanism is that the expansion of the foramen magnum facilitates the downward movement of the tonsils. Tonsils, which move to inferior, pull the anatomic structures they are attached to down. Arachnoid bands and adhesions at the level of tonsils may induce this process. Another facilitating factor is the effect of CDA. The higher CDA facilitates the movement of brainstem to the inferior. Additionally to this movement, tonsillar herniation together causes the compression around the foramen magnum, which is one of the reasons of syringomyelia.

Although the pathophysiology of the formation of syringomyelia has not been fully explained, defects of the CSF flow are important (8). Massive syringomyelia had been

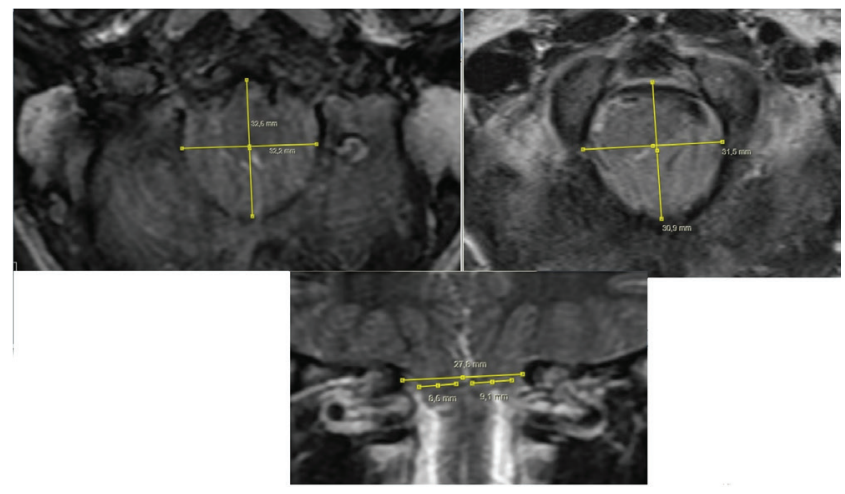

Figure 4. Examples of measurements of foramen magnum area at coronal and axial planes

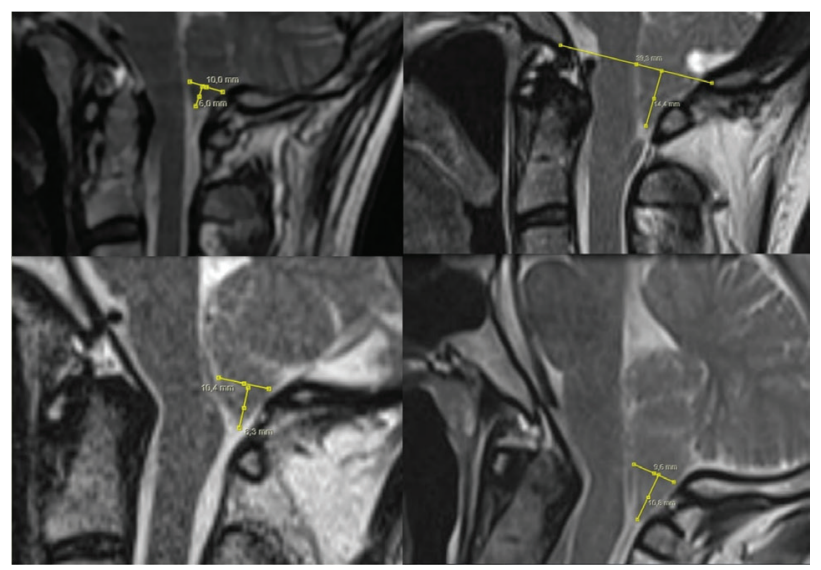

Figure 5. Examples of measurements of herniated tonsil volume at saggital plane

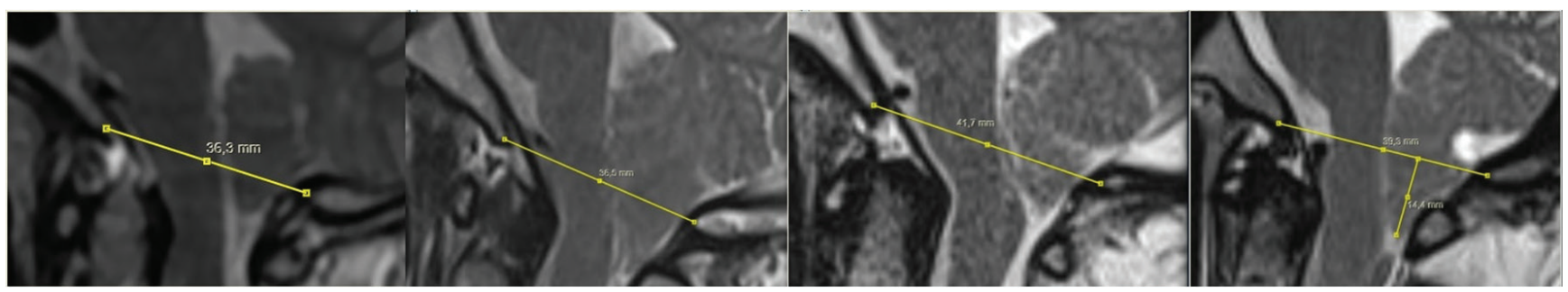

Figure 3. Examples of measurements of foramen magnum area at saggital plane 


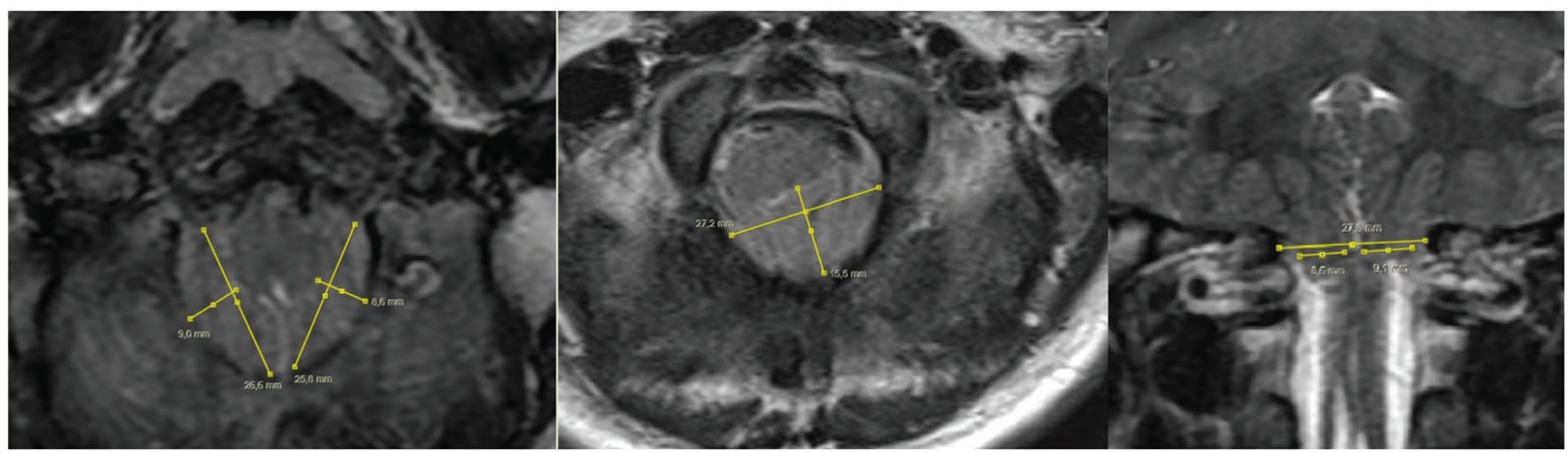

Figure 6. Examples of measurements of herniated tonsil volume at coronal and axial planes

Table 1. Age and morphometric values of operated and non-operated patients

\begin{tabular}{|l|l|l|l|l|l|}
\hline & Age (years) & FMA $\left(\mathbf{m m}^{2}\right)$ & HTV $\left(\mathbf{m m}^{\mathbf{3}}\right)$ & CDA (') & Syringomyelia (\%) \\
\hline Overall & $30.4 \pm 12.0$ & $765.2 \pm 119.5$ & $54.5 \pm 24.1$ & $139.5 \pm 10.6$ & 50 \\
\hline Operated & $27.7 \pm 10.4$ & $838.2 \pm 119.8$ & $66.2 \pm 19.9$ & $143.4 \pm 10.3$ & 60.6 \\
\hline Non-operated & $36.3 \pm 10.3$ & $721.9 \pm 108.2$ & $29.8 \pm 8.4$ & $131.1 \pm 5.2$ & 28.5 \\
\hline FMA: Foramen magnum area, HTV: Herniated tonsil volume, CDA: Clivo-dental angle \\
\hline
\end{tabular}

Table 2. Age and morphometric values according to syringmyelia presence

\begin{tabular}{|l|l|l|l|l|}
\hline & Age (years) & FMA $\left(\mathbf{m m}^{2}\right)$ & HTV $\left(\mathbf{m m}^{3}\right)$ & CDA $\left(^{\circ}\right)$ \\
\hline Patients with syringomyelia & $27 \pm 11.1$ & $876.5 \pm 131.9$ & $57.6 \pm 20.7$ & $141.1 \pm 10.2$ \\
\hline No syringomyelia & $33.9 \pm 12$ & $704.3 \pm 99.6$ & $51.4 \pm 26.8$ & $137.8 \pm 10.8$ \\
\hline Overall & $30.4 \pm 12.0$ & $765.2 \pm 119.5$ & $54.5 \pm 24.1$ & $139.5 \pm 10.6$ \\
\hline \multicolumn{2}{|l}{ FMA: Foramen magnum area, HTV: Herniated tonsil volume, CDA: Clivo-dental angle } \\
\hline
\end{tabular}

reported in acute worsening patients (9). We found the incidence of syringomyelia was $50 \%$ in all patients which is parallel to the literature (8). We also found HTV and accompanying syringomyelia were inversely proportional with age $(p<0.001)$ and were directly proportional with CDA $(p<0.001)$ and FMA $(p<0.001)$.

Growing anatomical structures which continues in younger patients and comes to an end in elder patients, may be responsible this negative correlation. One of another effect may be the mobility of neural structures in young patients. In this study tonsil herniation and syringomyelia were found to be more frequently in younger patients. Younger patients consist the majority of the cases who need surgery (10). Even if the older patients diagnosed as CM1, progressive disease and accompanying syringomyelia are very rare.

We found the young patients need surgery than older patients because of the tonsil herniation and accompanying syringomyelia. Also we found the increasing FMA and CDA cause more tonsil herniation and cooccurrence of syringomyelia.
It has been previously reported that the presence of syringomyelia is a factor that strengthens the indication for operation $(7,11)$. These findings may clarify the natural course of the disease and which factors are more frequent in operated patients. In addition, further studies are needed with more and different demographic people.

\section{Conclusion}

Younger age, larger FMA and CDA increase the HTV and the rate of accompanying syringomyelia. As a result, the need for surgery increases. We think that it may be beneficial to consider these parameters in patients who are evaluated for surgery.

\section{Authorship Contributions}

Concept: E.A., Design: A.K., Data Collection or Processing: E.A., A.K., Analysis or Interpretation: E.A., Literature Search: A.K., Writing: E.A., A.K.

Conflict of Interest: No conflict of interest was declared by the authors.

Financial Disclosure: The authors declared that this study received no financial support. 


\section{References}

1. Strahle J, Muraszko KM, Kapurch J, Bapuraj JR, Garton HJ, Maher CO. Natural history of Chiari malformation Type I following decision for conservative treatment. J Neurosurg Pediatr 2011;8214-21.

2. Novegno F, Caldarelli M, Massa A, et al. The natural history of the Chiari Type I anomaly. J Neurosurg Pediatr 2008;2:17987.

3. Chavez A, Roguski M, Killeen A, Heilman C, Hwang S. Comparison of operative and non-operative outcomes based on surgical selection criteria for patients with Chiari I malformations. J Clin Neurosci 2014;21:2201-6.

4. Killeen A, Roguski M, Chavez A, Heilman C, Hwang S. Nonoperative outcomes in Chiari I malformation patients. J Clin Neurosci 2015;22:133-8.

5. Bindal AK, Dunsker SB, Tew JM Jr. Chiari I malformation: classification and management. Neurosurgery 1995;37:106974.
6. Morris Z, Whiteley WN, Longstreth WT Jr, et al. Incidental findings on brain magnetic resonance imaging: systematic review and meta-analysis. BMJ 2009;339:3016.

7. Schuster JM, Zhang F, Norvell DC, Hermsmeyer JT. Persistent/ Recurrent syringomyelia after Chiari decompression-natural history and management strategies: a systematic review. Evid Based Spine Care J 2013;4:116-25.

8. Klekamp J, laconetta G, Samii M. Spontaneous resolution of Chiari I malformation and syringomyelia: case report and review of the literature. Neurosurgery 2001;48:664-7.

9. Almotairi FS, Tisell M. Acute deterioration of adults with Chiari I malformation associated with extensive syrinx. $\mathrm{Br}$ J Neurosurg 2020;34:13-7.

10. Massimi L, Della Pepa GM, Tamburrini G, Di Rocco C. Sudden onset of Chiari malformation Type I in previously asymptomatic patients. J Neurosurg Pediatr 2011;8:438-42.

11. Wilkins RH, Brady IA. The Arnold-Chiari malformations. Arch Neurol 1971:25:376-9. 